\title{
Increased Risk Of Cardiovascular Disease In Young Diabetics In Correlation With The Poor Glycemic Status And Dyslipidemia In A Tertiary Care Centre Of Upper Assam
}

\author{
Dr Arpita Ray*, Dr Ajit Kumar Pegu**, Dr Anupam Dutta*** \\ *Resident Physician, **Associate Professor, *** Assistant Professor \\ Department of Medicine, Assam Medical College and Hospital, Dibrugarh, ASSAM
}

\begin{abstract}
Diabetes Mellitus is considered to be a cardiovascular disease equivalent. The risk of CVD in DM is manifold, and the implications of the disease becomes even more grave when young diabetics die of cardiovascular diseases. The escalating number of young diabetics emphasises the need for early diagnosis and intervention when necessary to halt the progression of CVD. The present study is a novel attempt to assess the prevalence of CVD in young diabetics in upper Assam with poor glycemia and dyslipidemia with the aims and objectives to study the glycemic status and lipid profile in young diabetics and to study the CVD risk and involvement. It is a hospital based observational study carried over a period of 1 year which showed A total of 42.7\% of cardiovascular outcomes, of which Left Ventricular diastolic Dysfunction + Concentric LVH was found in $53.2 \%$ cases, Left Ventricular Diastolic Dysfunction alone was found in $21.8 \%$, Concentric LVH alone was found in $25 \%$. HbAlc level was found to be statistically extremely significant with the Cardiovascular Disease outcomes, with Left Ventricular Diastolic Dysfunction ( $p$ value 0.0007) and with Concentric LVH ( $p$ value 0.003). This was a hospital based observational study conducted in upper Assam among the patients with diabetes diagnosed at an early age of 25 years and below, to identify the presence of cardiovascular risks in young diabetes and the relation with glycemic status.
\end{abstract}

\section{Introduction}

Indians are predisposed to the early development of diabetes and its complications owing to certain genetic, clinical and biochemical abnormalities such as higher waist circumference, lower adiponectin and higher high sensitive C-reactive protein, which are part of the so called - "Asian Indian Phenotype" [1-3]

This phenotype makes Asian Indians more prone to diabetes and premature coronary artery disease.

It is a known fact that diabetic individuals are prone to cardiovascular diseases early in life, however, what is more alarming is the recent shift in the age of onset of the disease to a much younger age.

The ICMR-INDIAB study also showed that there is a shift of Type 2 DM to younger age groups and that the take off point of prevalence of diabetes occurs at ages 25-34 years in India.[4]

Type 1 DM was until recently considered the only form of diabetes in the young, however, of late, a large number of young diabetics have been found to be Type $2 \mathrm{DM}$. This is probably due to the alarming rates of obesity, the prevalence of both is so called - "Diabesity"

Indeed, the epidemic of T2DM is now spreading so rapidly, that already in some countries, like Japan; Type 2 DM is already more common than Type 1 DM, in children.[5,6]

There have been only few studies to evaluate the presence of cardiovascular involvement in young diabetics and its relation with the glycemic status in India, and as far as our knowledge goes, a methodical study to evaluate the cardiovascular risk factors in young diabetics has not been carried out in North East Assam. With consideration of the above facts, the present study is being conducted with the following Aims and Objectives :

Aims And Objectives:-

1) To study the glycemic status and lipid profile in young diabetics

2) To study the cardiovascular risk and cardiovascular involvement in young diabetics

\section{Materials And Method}

The present study 'Increased risk of cardiovascular disease in young diabetics in upper Assam in correlation with the poor glycemic status and dyslipidemia' is a hospital based observational study carried out on 75 patients of diabetes who were diagnosed at or below 25 years of age, who attended the Out Patient Department and / or were admitted in a Tertiary Care Hospital in Upper Assam during a period of one year from July 2014 to June 2015. 


\section{Selection of Cases:}

All young Diabetes Mellitus patients diagnosed at or below 25 years of age, attending the Out Patient Department and / or were admitted in a Tertiary Care Hospital in Upper Assam were included in the study after considering the inclusion criteria and exclusion criteria. Written informed consent from the patients / guardian was taken. Ethical clearance was obtained from the Ethics Committee of the Institution prior to the onset of study.

\section{Inclusion Criteria}

1) Young diabetics diagnosed at $\leq 25$ years of age.

2) Selection of cases of diabetes mellitus according to ADA 2015 guideline

\section{Exclusion Criteria}

- Diabetes Mellitus patients diagnosed above 25 years of age

- Diabetes Mellitus with Hypertension and/or Ischemic Heart Disease

- Patients on Lipid Lowering Therapy

- Family history of Hyperlipidemia

- Terminally Ill patients

- Pregnancy and Gestational DM

- Significant liver and renal disease

- Patients with severe anemia

Sample Size: After considering the inclusion and exclusion criteria, a total number of 75 cases were included in the present study

Study Design: Hospital based observational study

Method: A detailed clinical history, physical examination and investigations were done in all the patients and filled in a predesigned proforma

Case Definition of a case of Diabetes Mellitus was done according to the ADA 2015 guidelines - American Diabetes Association Diabetes Care 2015;38(Suppl. 1):S8-S16 [7]

The age of cut off of diagnosis at or below 25 years for young diabetic patients was chosen according to previous studies. $[4,8]$

$\mathrm{HbA} 1 \mathrm{c}$ of $<7 \%$ was considered good glycemic control, while a $\mathrm{HbA} 1 \mathrm{c}>7 \%$ was considered as poor glycemic control. The selection of these cutoff values of HbA1c was based on earlier studies $[9,10]$

The atherogenic index of plasma (AIP) was calculated by the formula base 10 logarithm of the ratio of TG to HDL.

An AIP of $>0.21$ was taken as high CAD risk, and $<0.21$ as low-intermediate CAD risk $[11,12]$

\section{Results And Observations}

The following tables illustrated the results of the present study:

Table .1: Gender Distribution Of Total Cases Of Young Diabetes

\begin{tabular}{|l|l|l|l|}
\hline SEX & NUMBER OF CASES $(\mathrm{N}=75)$ & PERCENTAGE\% & \multirow{2}{*}{ RATIO MALE:FEMALE } \\
\cline { 1 - 3 } MALE & 42 & 56 & \multirow{2}{*}{$\mathbf{1 . 2 7 : 1}$} \\
\cline { 1 - 3 } FEMALE & 33 & 44 & \\
\hline TOTAL & $\mathbf{7 5}$ & $\mathbf{1 0 0}$ & \\
\hline
\end{tabular}

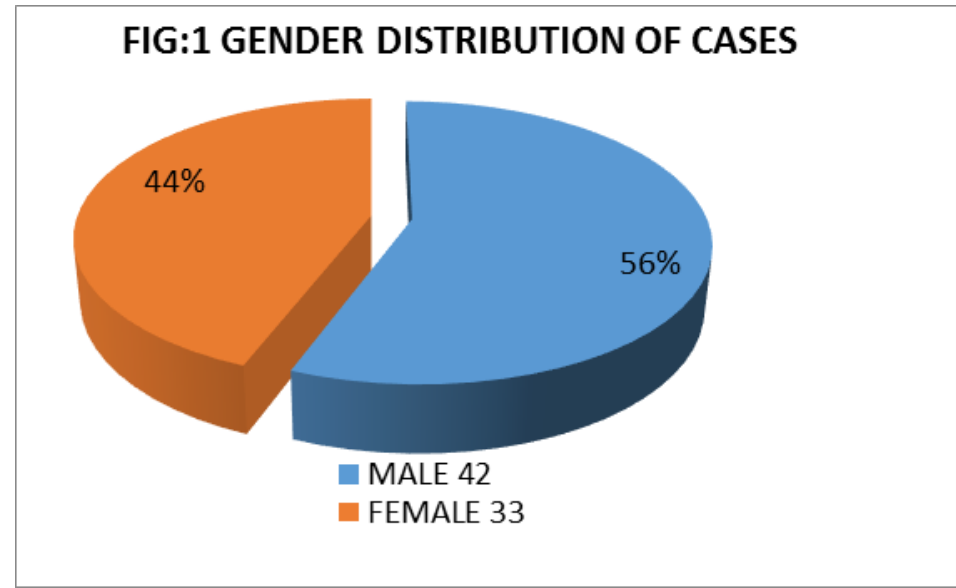


Increased Risk Of Cardiovascular Disease In Young Diabetics In Correlation With The ...

Table 2: Distribution Of Hba1c

\begin{tabular}{|c|c|c|}
\hline HBAIC & NUMBER OF CASES $(\mathrm{N}=75)$ & PERCENTAGE \% \\
\hline$\leq \mathbf{7}$ & 17 & 22.7 \\
\hline $\mathbf{7}$ & 58 & 77.3 \\
\hline TOTAL & $\mathbf{7 5}$ & $\mathbf{1 0 0}$ \\
\hline
\end{tabular}

FIG: 2 DISTRIBUTION OF HBA1C

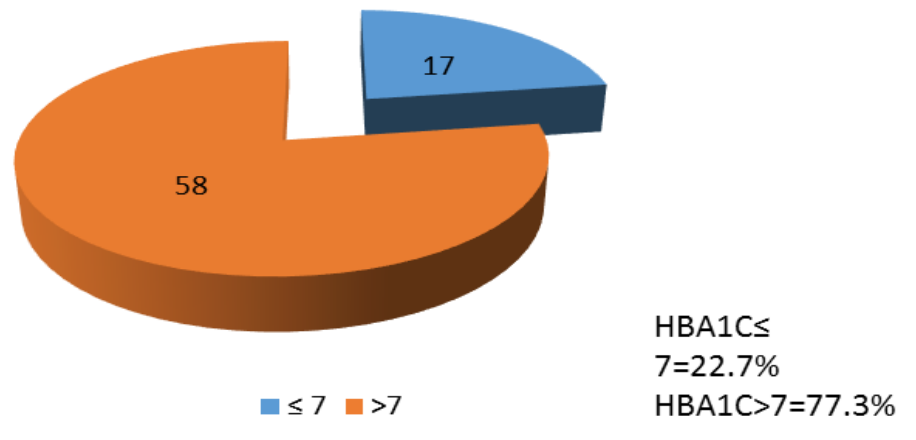

Table 3: Gender Distribution Of The Cardiovascular Outcomes

\begin{tabular}{|l|c|c|c|}
\hline PARAMETER & MALE [N=42] & FEMALE[N=33] & p- VALUE \\
\hline $\begin{array}{l}\text { LV DYSFUNCTION } \\
\text { PRESENT }\end{array}$ & 15 & 9 & 0.466 \\
\hline ABSENT & 27 & 24 & \\
\hline $\begin{array}{l}\text { CONCENTRIC LVH } \\
\text { PRESENT }\end{array}$ & 19 & 6 & 0.015 \\
\hline ABSENT & 23 & 27 & \\
(SIGNIFICANT)
\end{tabular}

$P$ value significant at $<0.05$

FIG :3 GENDER DISTRIBUTION OF THE CARDIOVASCULAR OUTCOMES

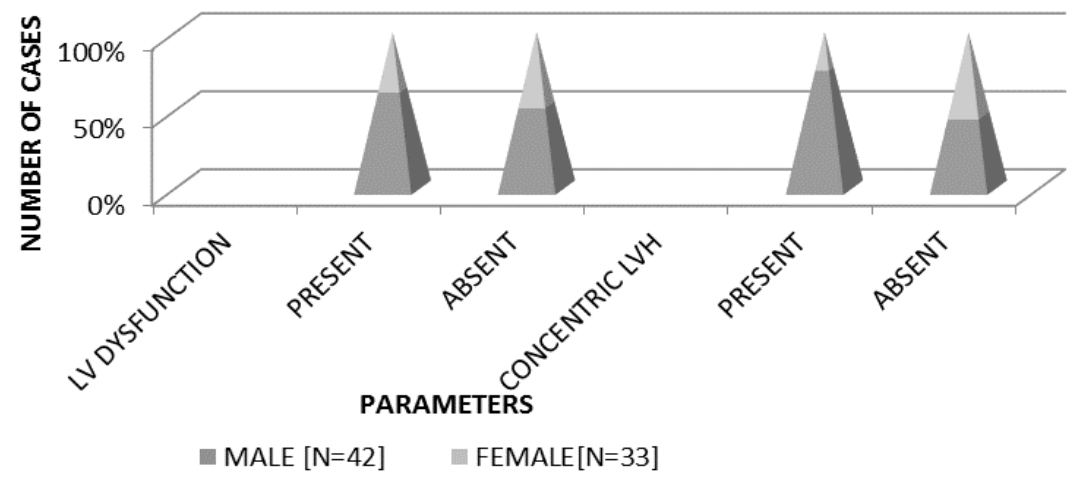

Table 4: Comparison Of Gender With Cvd Risk Factors And Type Of Dm And Treatment Given

\begin{tabular}{|l|l|l|l|}
\hline PARAMETERS & MALE [N=42] & FEMALE[N=33] & p- VALUE \\
\hline Age (Average \pm Standard Deviation) & $24.49 \pm 5.95$ & $23.61 \pm 7.15$ & 0.56 \\
\cline { 1 - 3 } $\begin{array}{l}\text { Duration of disease } \\
<1 \text { year (no.of cases) }\end{array}$ & 19 & 14 & \multirow{2}{*}{0.819} \\
\hline$>1$ year(no.of cases) & 23 & 19 & 0.67 \\
\hline BMI(Average \pm Standard Deviation) & $19.16 \pm 4.26$ & $19.59 \pm 4.47$ & 0.139 \\
\cline { 1 - 3 } HbA1c(Average \pm Standard Deviation) & $10.54 \pm 4.09$ & $9.23 \pm 3.31$ & 0.364 \\
\hline FBS(Average \pm Standard Deviation) & $298.57 \pm 129.87$ & $272.13 \pm 117.43$ & 0.817 \\
\hline Total Cholesterol(Average \pm Standard Deviation) & $167.49 \pm 53.68$ & $164.62 \pm 52.30$ & 0.500 \\
\hline Triglyceride(Average \pm Standard Deviation) & $162.78 \pm 89.28$ & $149.44 \pm 78.50$ & 0.137 \\
\hline HDL(Average \pm Standard Deviation) & $40.82 \pm 12.13$ & $45.68 \pm 15.91$ & 0.464 \\
\hline LDL(Average \pm Standard Deviation) & $90.36 \pm 42.85$ & $83.42 \pm 37.27$ & \\
\hline
\end{tabular}


Increased Risk Of Cardiovascular Disease In Young Diabetics In Correlation With The ...

\begin{tabular}{|c|c|c|c|}
\hline AIP(Average \pm Standard Deviation) & $0.57 \pm 0.33$ & $0.53 \pm 0.35$ & 0.613 \\
\hline $\begin{array}{l}\text { Microalbuminuria } \\
\text { PRESENT (no.of cases) }\end{array}$ & 27 & 18 & \multirow[t]{2}{*}{0.478} \\
\hline ABSENT(no.of cases) & 15 & 15 & \\
\hline $\begin{array}{l}\text { Type of DM } \\
\text { Type 1 DM(no.of cases) }\end{array}$ & 30 & 24 & \multirow[t]{2}{*}{1.0} \\
\hline Type 2 DM(no.of cases) & 12 & 9 & \\
\hline $\begin{array}{l}\text { Treatment Instituted } \\
\text { Insulin(no.of cases) }\end{array}$ & 30 & 26 & \multirow{3}{*}{0.366} \\
\hline OHA(no.of cases) & 10 & 4 & \\
\hline Both(no.of cases) & 2 & 3 & \\
\hline
\end{tabular}

Table 5: Distribution Of Hba1c With Lipid Parameters

\begin{tabular}{|c|c|c|}
\hline PARAMETERS & HbA1c $\square 7$ (no.=17) & HbA1c $>7($ no. $=58)$ \\
\hline CHOLESTEROL(mg/dl) & & \\
\hline$<200$ & 14 & 43 \\
\hline$\geq \mathbf{2 0 0}$ & 3 & 15 \\
\hline $\begin{array}{l}\text { TRIGLYCERIDE(mg/dl) } \\
<150\end{array}$ & 16 & 27 \\
\hline$\geq 150$ & 1 & 31 \\
\hline HDL(mg/dl) & & \\
\hline$<40$ & 0 & 24 \\
\hline$\geq \mathbf{4 0}$ & 17 & 34 \\
\hline LDL(mg/dl) & & \\
\hline$<100$ & 10 & 38 \\
\hline$\geq 100$ & 7 & 20 \\
\hline AIP & & \\
\hline$<0.21$ & 13 & 3 \\
\hline$\geq 0.21$ & 4 & 55 \\
\hline
\end{tabular}

FIG:5 DISTRIBUTION OF HBA1C WITH LIPID PARAMETERS

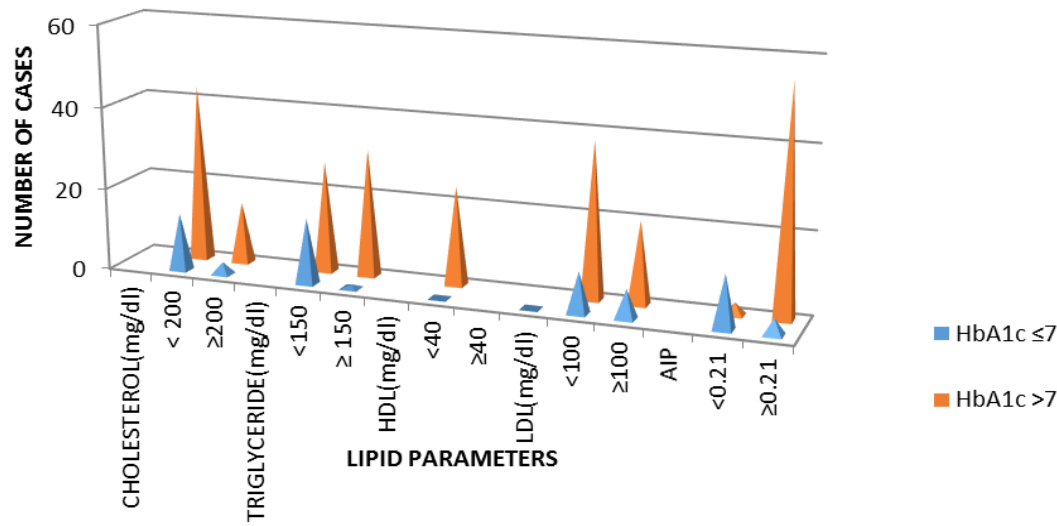

Table 6: Distribution Of Hba1c Levels With The Cardiovascular Outcomes

\begin{tabular}{|c|c|c|c|}
\hline PARAMETERS & HbA1c $\leq 7($ no. $=17)$ & HbA1c $>7($ no. $=58)$ & P VALUE \\
\hline $\begin{array}{l}\text { LV DYSFUNCTION } \\
\text { PRESENT(no.of cases) }\end{array}$ & $0(0 \%)$ & $24(41.4 \%)$ & 0.0007 \\
\hline ABSENT(no.of cases) & $17(100 \%)$ & $34(58.6 \%)$ & SIGNIFICANT \\
\hline ABSENT(no.of cases) & $17(100 \%)$ & $33 \quad(56.9 \%)$ & SIGNIFICANT \\
\hline
\end{tabular}




\section{FIG: 6 DISTRIBUTION OF HbA1c LEVELS WITH THE CARDIOVASCULAR OUTCOMES}

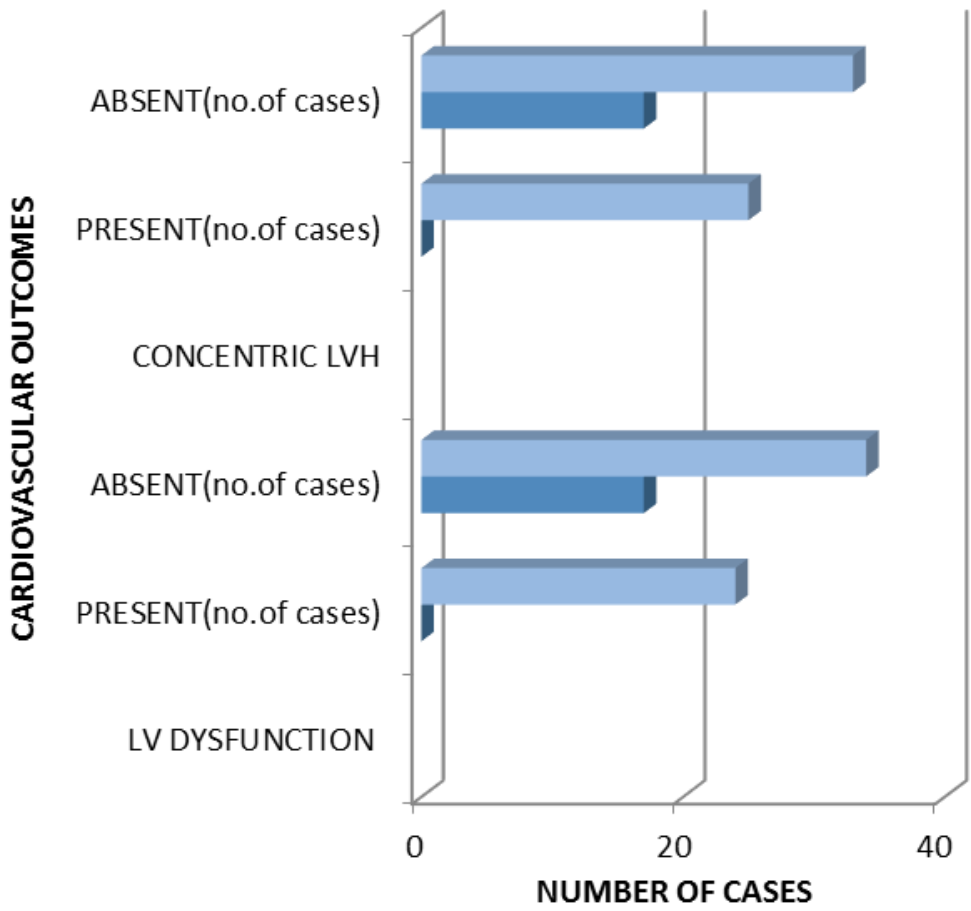

TABLE 7

COMPARISON OF HbA1C LEVELS WITH CVD RISK FACTORS AND TYPE OF DM

\begin{tabular}{|c|c|c|c|}
\hline PARAMETERS & $\begin{array}{c}\text { HbA1c } \square 7 \\
\text { (no.=17) }\end{array}$ & HbA1c $>7($ no. $=58)$ & P-value \\
\hline Age (Mean \pm Standard Deviation) & $22.97 \pm 6.45$ & $24.43 \pm 6.50$ & 0.417 \\
\hline $\begin{array}{l}\text { Duration of disease } \\
<1 \text { year (no.of cases) } \\
\end{array}$ & 7 & 26 & \\
\hline >1 year(no.of cases) & 10 & 32 & 0.79 \\
\hline BMI(Mean \pm Standard Deviation $)$ & $19.03 \pm 2.96$ & $19.44 \pm 4.67$ & 0.734 \\
\hline FBS(Mean \pm Standard Deviation) & $213.71 \pm 94.4$ & $308.4 \pm 124.62$ & 0.005 \\
\hline PPBS(Mean \pm Standard Deviation) & $277.44 \pm 150.22$ & $405.51 \pm 131.85$ & 0.001 \\
\hline $\begin{array}{c}\text { Total Cholesterol(Mean } \pm \text { Standard } \\
\text { Deviation) }\end{array}$ & $157.29 \pm 44.82$ & $168.84 \pm 54.92$ & 0.431 \\
\hline Triglyceride(Mean \pm Standard Deviation) & $92.18 \pm 34.79$ & $175.88 \pm 85.41$ & 0.0002 \\
\hline HDL(Mean \pm Standard Deviation) & $56.82 \pm 10.46$ & $38.89 \pm 12.28$ & 0.0001 \\
\hline LDL(Mean \pm Standard Deviation) & $90.52 \pm 42.62$ & $86.36 \pm 40.03$ & 0.711 \\
\hline AIP(Mean \pm Standard Deviation) & $0.19 \pm 0.14$ & $0.66 \pm 0.31$ & 0.0001 \\
\hline $\begin{array}{c}\text { Microalbuminuria } \\
\text { PRESENT (no.of cases) }\end{array}$ & 2 & 43 & $<0.00001$ \\
\hline ABSENT(no.of cases) & 15 & 15 & \\
\hline $\begin{array}{cl}\text { Type of DM } \\
\text { Type } 1 \text { DM(no.of cases) }\end{array}$ & 11 & 43 & \\
\hline
\end{tabular}


Increased Risk Of Cardiovascular Disease In Young Diabetics In Correlation With The ...

\begin{tabular}{|c|c|c|c|}
\hline Type 2 DM(no.of cases) & 6 & 15 & 0.54 \\
\hline $\begin{array}{c}\text { Treatment Instituted } \\
\text { Insulin(no.of cases) }\end{array}$ & 13 & 43 & \\
\hline OHA(no.of cases) & 4 & 10 & 1.756 \\
\hline Both(no.of cases) & 0 & 5 & \\
\hline
\end{tabular}

Significant $p$ value at $<0.05$

TABLE 8

COMPARISON OF THE TREATMENT INSTITUTED WITH THE CVD OUTCOMES

\begin{tabular}{|l|c|c|c|c|}
\hline PARAMETERS & INSULIN [N=56] & OHA [N=14] & BOTH [N=5] & P VALUE \\
\hline LV DYSFUNCTION & & & & \\
PRESENT & 16 & 5 & 3 & 0.33 \\
\hline ABSENT & 40 & 9 & 2 & \\
\hline CONCENTRIC LVH & & & & 0.253 \\
PRESENT & 16 & 6 & 3 & \\
\hline ABSENT & 40 & 8 & 2 & 0.139 \\
\hline Microalbuminuria & & & & \\
PRESENT & 31 & 9 & 5 & \\
\hline ABSENT & 25 & 5 & 0 & 0.764 \\
\hline AIP & 13 & & & \\
\hline <0.21 & 43 & 12 & & \\
\hline 0.21 & & & & \\
\hline
\end{tabular}

Significant value of $p$ at $<0.05$

FIG : 7 COMPARISON OF THE TREATMENT INSTITUTED WITH THE CVD OUTCOMES

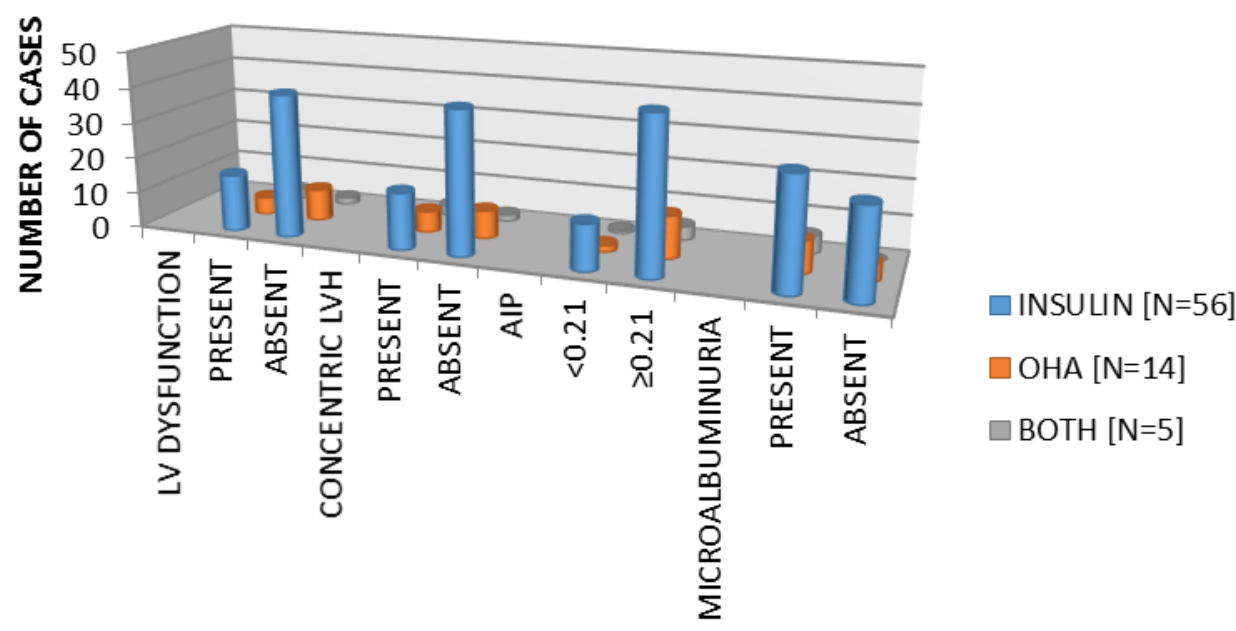

CVD OUTCOMES

TABLE 9

DISTRIBUTION OF THE LIPID PARAMETERS WITH VARYING HbA1c LEVELS TO SHOW CORRELATION

\begin{tabular}{|c|c|c|c|c|c|}
\hline $\begin{array}{c}\text { LIPID } \\
\text { PARAMETERS(mg/dl) }\end{array}$ & $\begin{array}{c}\text { HbA1C } \leq 7 \\
{[\mathrm{~N}=17]}\end{array}$ & $\begin{array}{c}\text { HbA1C 7.1-8 } \\
{[\mathrm{N}=16]}\end{array}$ & $\begin{array}{c}\text { HbA1C 8.1-9.5 } \\
{[\mathrm{N}=11]}\end{array}$ & $\begin{array}{c}\text { HbA1C } \\
\geq 9.5\end{array}$ & P VALUE \\
\hline
\end{tabular}


Increased Risk Of Cardiovascular Disease In Young Diabetics In Correlation With The ...

\begin{tabular}{|c|c|c|c|c|c|}
\hline & & & & {$[\mathrm{N}=31]$} & \\
\hline \multicolumn{5}{|c|}{ TOTAL CHOLESTEROL } & \multirow{3}{*}{0.817} \\
\hline$<200$ & 14 & 11 & 8 & 24 & \\
\hline$\geq 200$ & 3 & 5 & 3 & 7 & \\
\hline TRIGLYCE & & & & & \multirow{3}{*}{0.0065} \\
\hline$<150$ & 16 & 8 & 5 & 14 & \\
\hline$\geq 150$ & 1 & 8 & 6 & 17 & \\
\hline \multicolumn{5}{|l|}{ HDL } & \multirow{3}{*}{0.0044} \\
\hline$<40$ & 0 & 4 & 5 & 15 & \\
\hline$\geq 40$ & 17 & 12 & 6 & 16 & \\
\hline \multicolumn{5}{|l|}{ LDL } & \multirow{3}{*}{0.462} \\
\hline$<100$ & 10 & 8 & 8 & 22 & \\
\hline$\geq 100$ & 7 & 8 & 3 & 9 & \\
\hline
\end{tabular}

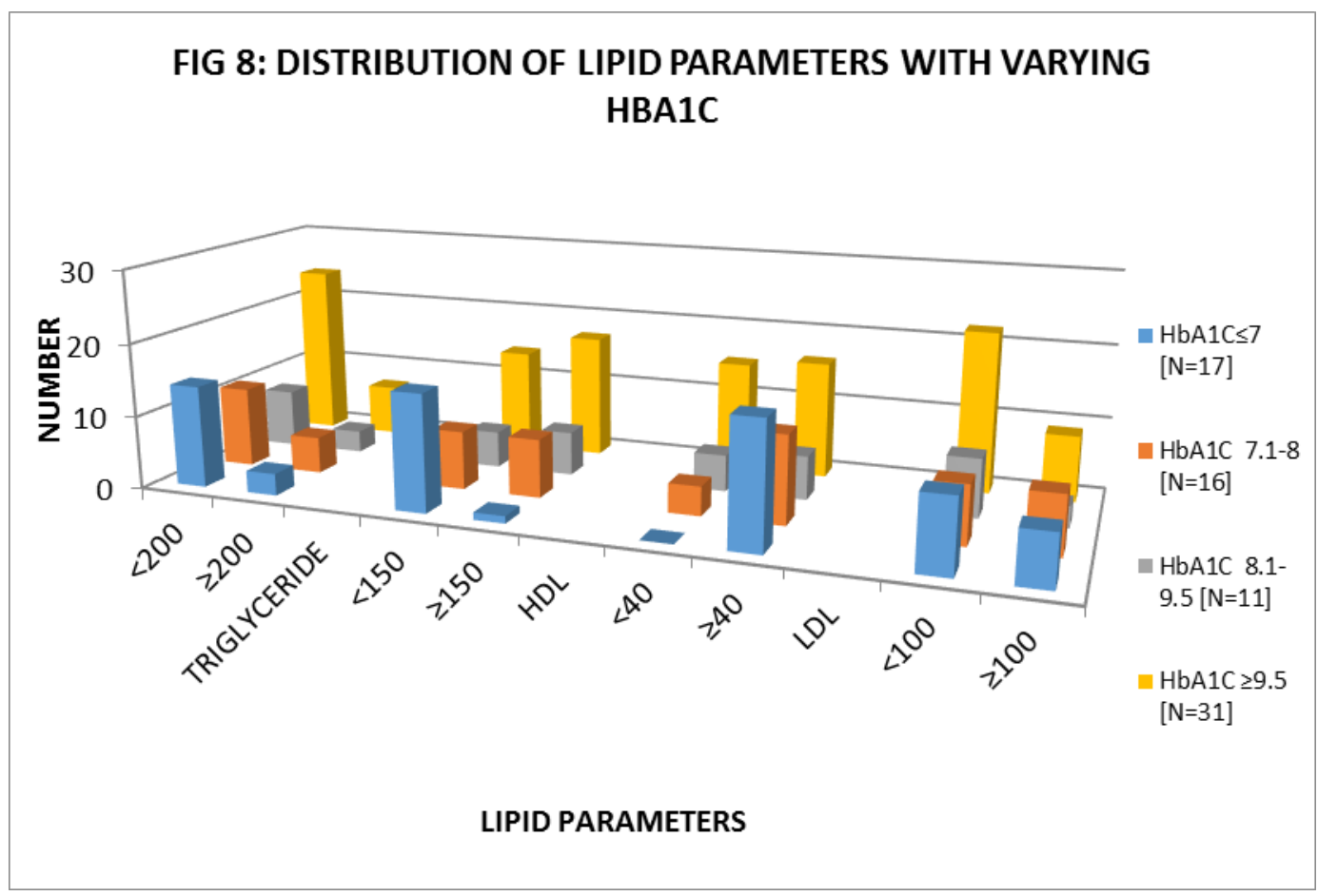

TABLE 10

DISTRIBUTION OF HbA1C LEVELS WITH CVD RISK FACTORS AND CVD OUTCOMES

\begin{tabular}{|c|c|c|c|c|c|}
\hline CVD PARAMETERS & $\begin{array}{c}\mathrm{HbA} 1 \mathrm{C} \\
\leq 7 \\
{[\mathrm{~N}=17]}\end{array}$ & $\begin{array}{c}\mathrm{HbA} 1 \mathrm{C} \\
7.1-8 \\
{[\mathrm{~N}=16]}\end{array}$ & $\begin{array}{c}\mathrm{HbA} 1 \mathrm{C} \\
8.1-9.5 \\
{[\mathrm{~N}=11]}\end{array}$ & $\begin{array}{c}\mathrm{HbA} 1 \mathrm{C} \\
\geq 9.5 \\
{[\mathrm{~N}=31]}\end{array}$ & P VALUE \\
\hline AIP & & & & & \\
\hline
\end{tabular}


Increased Risk Of Cardiovascular Disease In Young Diabetics In Correlation With The ...

\begin{tabular}{|c|c|c|c|c|c|}
\hline$<0.21$ & 13 & 2 & 0 & 1 & \multirow[t]{2}{*}{$<0.00001$} \\
\hline$\geq 0.21$ & 4 & 14 & 11 & 30 & \\
\hline \multicolumn{5}{|c|}{ TYPE OF DM } & \multirow{3}{*}{0.224} \\
\hline TYPE1 & 11 & 11 & 6 & 26 & \\
\hline TYPE2 & 6 & 5 & 5 & 5 & \\
\hline \multicolumn{5}{|c|}{ MICROALBUMINURIA } & \multirow{3}{*}{$<0.000045$} \\
\hline PRESENT & 2 & 10 & 8 & 25 & \\
\hline ABSENT & 15 & 6 & 3 & 6 & \\
\hline \multicolumn{5}{|c|}{$\begin{array}{l}\text { LV DIASTOLIC } \\
\text { DYSFUNCTION }\end{array}$} & \multirow{3}{*}{0.00334} \\
\hline PRESENT & 0 & 5 & 7 & 12 & \\
\hline ABSENT & 17 & 11 & 4 & 19 & \\
\hline \multicolumn{5}{|c|}{ CONC LVH } & \multirow{3}{*}{0.0053} \\
\hline PRESENT & 0 & 5 & 6 & 14 & \\
\hline ABSENT & 17 & 11 & 5 & 17 & \\
\hline \multicolumn{5}{|c|}{ TREATMENT GIVEN } & \multirow{4}{*}{0.507} \\
\hline INSULIN & 13 & 12 & 6 & 25 & \\
\hline OHA & 4 & 3 & 3 & 4 & \\
\hline ВОТН & 0 & 1 & 2 & 2 & \\
\hline
\end{tabular}

\section{FIG 9:DISTRIBUTION OF HBA1C WITH CVD RISK FACTORS AND CVD OUTCOME}

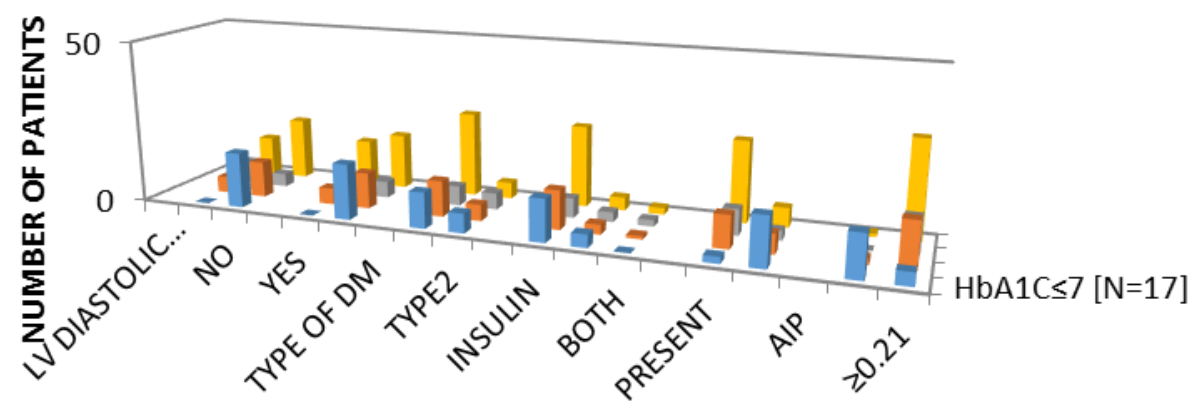

CVD RISK FACTORS AND CVD OUTCOMES

$$
\begin{aligned}
& \square \mathrm{HbA} 1 \mathrm{C} \leq 7[\mathrm{~N}=17] \quad \mathrm{HbA} 1 \mathrm{C} 7.1-8[\mathrm{~N}=16] \\
& \mathrm{HbA} 1 \mathrm{C} 8.1-9.5[\mathrm{~N}=11] \square \mathrm{HbA} 1 \mathrm{C} \geq 9.5[\mathrm{~N}=31]
\end{aligned}
$$

\section{DISCUSSION}


The present study included 75 patients, ranging from the age of 13 to 40 years, who were diagnosed at or below 25 years of age. The mean age of diagnosis was $24.11 \pm 6.45$ years. The majority of the patients were male (42 patients ) with $56 \%$, while females(33) were $44 \%$. The male to female ratio in the study was found to be 1.27:1. These data were comparable to other studies conducted by SEARCH, to study the 'Glucose Control Predicts 2-Year Change in Lipid Profile in Youth with Type 1 Diabetes' and by SEARCH, to study the 'Serum Lipids and Glucose Control'. The data were also comparable to a study conducted by Soedamah-Muthu et al, 2006, to determine the the absolute and relative risk of cardiovascular disease (CVD) in patients with type 1 diabetes in the U.K.

In the study the distribution of HbAlc was $>7$ was $77.3 \%$ and $\leq 7$ was $22.7 \%$. Among the males with poor control of diabetes with $\mathrm{HbA} 1 \mathrm{c}>7$ was $58.6 \%$, while females were $41.4 \%$. The average and standard deviation found in males was $10.54 \pm 4.09$ and among the females was $9.23 \pm 3.31$, which was not found to be statistically significant with $\mathrm{p}$ value of 0.139 .

The distribution of the lipid parameters and glycemic status among the HbAlc $<7$ and $\geq 7$ were found to be statistically significant for the FBS, PPBS, Triglycerides, HDL and AIP with p value of $<0.005$. However it was not found to be significant with LDL, Total cholesterol and BMI.

On comparison of the glycemic control it was seen that HbA1c was found to be statistically significantly related with certain CVD risk factors such as Triglyceride (risk at $\geq 150 \mathrm{mg} / \mathrm{dl}$ ), HDL (risk at $<40 \mathrm{mg} / \mathrm{dl}$ ), AIP, microalbumiuria.[11,13-15]

This is supported by study conducted by Maahs et al, SEARCH to study the 'Glucose Control Predicts 2-Year Change in Lipid Profile in Youth with Type 1 Diabetes' [16] where they found that change in A1c over time was significantly associated with changes in Total Cholesterol, HDL-c, LDL-c, TG, and non-HDL-c over the range of A1c values.

In a study conducted by SEARCH, to study the 'Serum Lipids and Glucose Control'[180] they found that lipid levels increase with increasing values of $\mathrm{HbA1c}$, a very high percentage of youth are classified as having "high" Total Cholesterol , LDL-C, and triglyceride concentrations in the category "poor glycemic control" for both type 1 and type 2 diabetes.

Among the cardiovascular outcomes, a total of 32 / 75 (42.7\%) outcomes were found, of which Left Ventricular Dysfunction was found along with Concentric LVH in 17 / 32 (53.2\%) cases, Left Ventricular Dysfunction alone was found in $7 / 32$ (21.8\%), and Concentric LVH was found alone in 8 / 32 (25\%) cases.

Poor glycemic control with HbA1c $>7$ was found to be statistically extremely significant with the CVD outcomes.

CVD outcomes were found to be statistically significantly related to microalbuminuria, however it was not significantly related to the treatment options instituted

In a study conducted by SEARCH, to study the 'Prevalence of Cardiovascular Disease Risk Factors in U.S. Children and Adolescents With Diabetes' [17], The prevalence of having at least two CVD risk factors was $21 \%$. The prevalence was $7 \%$ among children aged 3-9 years and $25 \%$ in youth aged $10-19$ years $(P<0.0001)$, $23 \%$ among girls and $19 \%$ in boys $(P=0.04)$, At least two CVD risk factors were present in $92 \%$ of youth with type 2 and $14 \%$ of those with type 1 diabetes $(P<0.0001)$.

The Pittsburgh Epidemiology of Diabetes Complications (EDC) study demonstrated that the incidence of major coronary artery disease (CAD) events in young adults (aged 28-38 years) with T1DM was $0.98 \%$ per year and surpassed $3 \%$ per year after age 55 years, which makes it the leading cause of death in that population.[18,19] An increased risk of CVD has been reported in other studies, with the age-adjusted relative risk (RR) for CVD in T1DM being $\approx 10$ times that of the general population.[13,20]

One of the most robust analyses of CVD risk in this disease derives from the large UK General Practice Research Database (GPRD), comprising data from $>7400$ patients with T1DM with a mean \pm SD age of $33 \pm 14.5$ years and a mean DM duration of $15 \pm 12$ years. 8 CVD events in the UK GPRD study occurred on average 10 to 15 years earlier than in matched non diabetic control subjects.[21] The findings of the study were hence comparable with the rest of the studies.

There have been very few studies to assess the cardiovascular involvement in young diabetics, and echocardiographic assessment studies in young diabetics are rare. We see in the present study that $42.7 \%$ of the patients had echocardiographic evidence of cardiovascular involvement, however we did not find evidence of ischemia or myocardial infarction. The present study was an observational study with echocardiographic findings which were subclinical as compared to the other prospective cohort studies.

This finding was probably due to the duration of study being restricted to one year period as compared to other studies conducted over several years and over a larger population

The echocardiographic findings of the present study is novel, in upper Assam, as far as our knowledge goes.

A study conducted by J.N.khan et al, [22] also supports our finding. They had assessed the presence of 
subclinical diastolic dysfunction in young diabetics below 40 years of age using cardiovascular contrast enhanced magnetic resonance and found that In the Type 2 DM cohort, mean aortic distensibility correlated with peak early diastolic strain rate (PEDSR), $(\mathrm{r}=0.564, \mathrm{P}=0.023)$

\section{CONCLUSION}

Diabetes mellitus in young is a major concern owing to the increased mortality and morbidity associated with the disease. The increased mortality in the young diabetics is majorly due to the cardiovascular disease. In the present study we see that a large number of patients were diagnosed to have diabetes at a younger age (diagnosed at and below 25 years of age) in North East India, especially upper Assam.

Majority of the young diabetic patients had very poor glycemic control and dyslipidemia, both of which, along with genetic and other environmental factors create an atherogenic milieu that probably contributes to the increased cardiovascular risk.

In the present study we found that the level of $\mathrm{HbAlc}$ correlated with the various atherogenic lipid parameters and the increase in the level of $\mathrm{HbAlc}$ was associated with increased cardiovascular risk factors such as increased level of Triglyceride $\geq 150 \mathrm{mg} / \mathrm{dl}$, decreased level of $\mathrm{HDL}<40 \mathrm{mg} / \mathrm{dl}$, Atherogenic Index Of Plasma (AIP) $\geq 0.21$ and microalbuminuria. The levels of $\mathrm{HbAlc}$ also corresponded positively with the cardiovascular outcomes such as Left Ventricular Diastolic Dysfunction and Concentric Left Ventricular Hypertrophy.

It is therefore extremely important to have a strong clinical suspicion in order to look for the presence of cardiovascular risk factors in young patients with diabetes with uncontrolled glycemic status as it predisposes the patients to early development of cardiovascular disease.

This was a hospital based observational study conducted in upper Assam among the patients with diabetes diagnosed at an early age of 25 years and below, to identify the presence of cardiovascular risks in young diabetes and the relation with glycemic status. As far as our knowledge goes, the present study is a pioneer study conducted in upper Assam, in young patients with diabetes. The study emphasizes on the need for early diagnosis of cardiovascular risks and thereby early intervention to reduce the morbidity and mortality associated with the disease in the young patients.

\section{References}

[1]. Ramachandran A, Jali MV, Mohan V, Snehalatha C, Viswanathan M. High prevalence of diabetes in an urban population in south India. BMJ 1988;297:587-90.

[2]. Sridhar GR, Rao PV, Ahuja MMS. Epidemiology of diabetes and its complications. In: RSSDI textbook of diabetes mellitus. Hyderabad: Research Society for the Study of Diabetes in India; 2002 p. 95-112.

[3]. Rao PV, Ushabala P, Seshaiah V, Ahuja MMS, Mather HM. The Eluru survey: prevalence of known diabetes in a rural Indian population. Diabetes Res Clin Pract 1989; $7: 29-31$.

[4]. Anjana RM, Pradeepa R, Deepa M, et al. Prevalence of diabetes and prediabetes (impaired fasting glucose and/or impaired glucose tolerance) in rural and urban India: phase 1 results of the Indian Council of Medical Research-India DIABetes (ICMR INDIAB) study. Diabetologia. 2011;54(12):3022-7

[5]. Kitagawa T, Owada M, Urakami T, et al. Increased incidence of non-insulin dependent diabetes mellitus among Japanese school children correlates with an increased intake of animal protein and fat, Clin Pediatr. 1998;37(2):11-5.

[6]. Kida K. Obesity and type II diabetes in childhood. In Proceedings of Diabetes in Asia, 2002. Colombo, Sri Lanka. Diabetes Association of Sri Lanka; 2002.p.44.

[7]. American Diabetes Association. Classification and diagnosis of diabetes. Sec. 2. In Standards of Medical Care in Diabetes 2015. Diabetes Care 2015;38(Suppl. 1):S8-S16

[8]. Pettitt DJ, Talton J, Dabelea D, Divers J, Imperatore G, 5. Lawrence JM, et al. SEARCH for Diabetes in Youth Study Group. Prevalence of diabetes in U.S. youth in 2009: the SEARCH for diabetes in youth study. Diabetes Care 2014; $37: 402-8$.

[9]. Position statement, Standards of Medical Care in Diabetes-2012, Diabetes Care, 35 (1), 2012, S11-S63

[10]. The Diabetes Control and Complications Trial Research Group. The effect of intensive treatment of diabetes on the development and progression of long-term complications in insulin-dependent diabetes mellitus.N Engl JMed 1993;329:977-986 [123] Ohkubo Y, Kishikawa H, Araki

[11]. Milada Dobia's šva, Atherogenic Index of Plasma [Log(Triglycerides/HDLCholesterol)]: Theoretical and Practical Implications. Clin. Chem., 50 (7): Editorial (2004).

[12]. Dobiasova M, Frohlich J, The plasma parameter log (TG/HDL-C) as an atherogenic index: correlation with lipoprotein particle size and esterification rate in apoB-lipoprotein-depleted plasma (FER(HDL), Clin Biochem, 34(7), 2001, 583-588.

[13]. National Heart, Lung, and Blood Institute: Executive summary of the Third Report of the National Cholesterol Education Program (NCEP) Expert Panel on Detection, Evaluation, and Treatment of High Blood Cholesterol in Adults (Adult Treatment Panel III). JAMA 285:2486-2497, 2001

[14]. Yoo EG, Choi IK, Kim DH: Prevalence of microalbuminuria in young patients with type 1 and type 2 diabetes mellitus. J Pediatr Endocrinol Metab 17:1423-1427, 2004

[15]. Ettinger LM, Freeman K, Dimartino- Nardi JR, Flynn JT: Microalbuminuria and abnormal ambulatory blood pressure in adolescents with type 2 diabetes mellitus. J Pediatr 147:67-73, 2005

[16]. Di Bello V, Talarico L, Picano E, Di Muro C, Landini L, Paterni M, Matteucci E, Giusti C, Giampietro O: Increased echodensity of myocardial wall in the diabetic heart: an ultrasound tissue characterization study. J Am Coll Cardiol 1995;25:1408-1415.

[17]. Salem M, El Behery S, Adly A, Khalil D, El Hadidi E: Early predictors of myocardial disease in children and adolescents with type 1 diabetes mellitus. Pediatr Diabetes 2009; 10:513-521

[18]. Sacks DB, Bruns DE, Goldstein DE, Maclaren NK, McDonald JM, Parrott M. Guidelines and recommendations for laboratory analysis in the diagnosis and management of diabetes mellitus. Clin. Chem. 2002; 48: 436-472. 
[19]. Conolly HM, Oh JK. Echocardiography. In: Bonow RO, Mann DL, Zipes DP, Libby P, Braunwald E (eds.)Braunwald_s Heart Disease A Textbook of Cardiovascular Medicine. 9th Edition. Saunders, Elsevier, 2012:200- 276.

[20]. SEARCH for Diabetes in Youth Study, Diana B. Petitti, MD, MPH et al, , Arch Pediatr Adolesc Med. 2007;161:159-165

[21]. Nagueh SF, Middleton KJ, Kopelen HA, Zoghbi WA, Quinones MA: Doppler tissue imaging: a noninvasive technique for evaluation of left ventricular relaxation and estimation of filling pressures. J Am Coll Cardiol 1997;30: 1527-1533

[22]. J.N.Khan et al , European Heart Journal - Cardiovascular Imaging (2014) 15, 1263-1269 doi:10.1093/ehjci/jeu121 